Journal of Jazz Studies vol. 9, no. 2, pp. 190-214 (Winter 2013)

\title{
Starting with the ABC and HR of It A Conversation on the State of Jazz Education with Five Renowned Jazz Educators
}

\author{
Jerry Tolson
}

The lyrics of a well-known standard tune state:

Starting with the $A B C$ of it;

Right down to the $X Y Z$ of it;

Help me solve the mystery of it,

Teach me tonight.

In its early history, learning jazz was primarily an aural endeavor that required extensive listening and rote memorization with little written documentation, no organized or published methods, and no formal educational process. Throughout the history of the music, for many students and aspiring jazz musicians, learning to play jazz has been somewhat of an elusive mystery. The challenge of solving that mystery can involve hours of listening, transcribing, and practice. A step-by-step, systematic process to unlock the mysteries of this complex music has not always been readily available. Efforts to codify instruction in jazz began as early as the 1930s and 40s especially in places such as the Great Lakes Naval Base, and transcriptions and "how to" articles began to appear in magazines such as Down Beat. ${ }^{1}$ About 40-50 years ago, a number of educators began to put together organized, sequential ideas for learning this music in a logical fashion. The names Aebersold, Baker, Coker, Haerle, and Reid are among the most recognized in jazz education. They were among the pioneers in developing and creating practical methods and materials to approach learning how to play jazz and improvise.

Jamey Aebersold has long been known as the play-a-long king, developing a sort of music minus one format for practicing jazz to a recorded rhythm section using the chord-scale approach to improvisation. David Baker wrote a seminal text on jazz pedagogy and has been the director the Indiana University

\footnotetext{
${ }^{1}$ Daniel Murphy, "Jazz Studies in American Schools and Colleges: a Brief History," Jazz Educators Journal, Vol. 26 (1994): 34-38 excerpted from "Jazz in

America: Education" accessed on September 27, 2013.

http://www.jazzinamerica.org/JazzResources/JazzEducation/Page/162 accessed September 27, 2013.
}

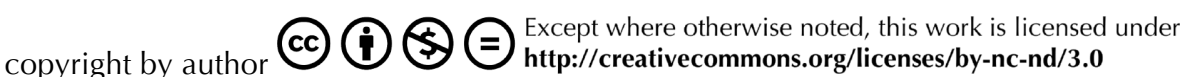


jazz program for close to 50 years. Jerry Coker pioneered programs at Indiana University, the University of Miami, and the University of Tennessee and has written numerous jazz education books including the very highly regarded "Patterns for Jazz." Dan Haerle has also written a number of jazz education books and has been active in the development of the programs at Monterey Peninsula College, the University of Miami, Arizona State University, and the University of North Texas. Rufus Reid spent many years on the road and recording with a who's who list of jazz artists, as well as 20 years as the director of the jazz program at William Paterson University. His signature text, "The Evolving Bassist," remains a top choice for jazz bass instruction. All of these jazz educators have had varied experiences in both formal and informal teaching environments and were among the early leaders in the fields of educational jazz publications and jazz education at the college level. (For more information on these educators, refer to the biographies at the end of this article).

One of the best-known jazz education environments is the annual Jamey Aebersold Summer Jazz Workshop. Since its creation in 1972, jazz musicians of all ages and abilities have had the opportunity to hone and develop their skills. Originally held in numerous locations around the country, the workshop is now held for two consecutive weeks on the campus of the University of Louisville in Louisville, KY. Several two-day mini-workshops are held at other sites around the country. Many well known jazz artists have taught at the camp including Joe Henderson, Freddie Hubbard, James Moody, Dave Liebman, Slide Hampton, Jon Faddis, Bobby Shew, Antonio Hart, and Tom Harrell. Likewise, there are many now famous jazz artists who spent time sharpening their skills at this camp. Among them are saxophonist Chris Potter, trumpeter Sean Jones, and pianists Geoff Keezer and the late James Williams.

All of the educators that were interviewed for this article have spent many years teaching at this camp. Their record of success both as performers and educators speaks for itself. I have had the honor of working with all of these gentlemen at the workshop as a fellow faculty colleague for the last twenty years and have learned much from them about the music and about teaching the music. It was interesting to discover how each of them got their start teaching a style of music that for a long time many thought could not be taught in any formal fashion. Likewise, they began teaching at a time when jazz was still not widely accepted let alone considered worthy of study. There were also few materials available to use to teach the music at the time they began. So, this interview was enlightening as to how they began to develop their own materials to teach jazz and the challenges they faced in developing college-level jazz studies programs. The teaching materials that they created 
have become some of the quintessential jazz education materials used by amateurs and pros alike to learn and study this challenging art form.

When I began my teaching career as a high school band director, I used the Aebersold play-a-long records and the Coker and Haerle books to instruct young aspiring jazz players. I also used them to develop my own performance and teaching skills. While attending the University of North Texas for graduate work, I had the opportunity to study with Haerle. After assuming a faculty teaching position in 1993 at the University of Louisville, where at the time Aebersold was still teaching, I was offered the opportunity to join the Summer Jazz Workshop faculty. At a recent Summer Jazz Workshop, and shortly before Jerry Coker announced his retirement from teaching at the workshop, I cornered each of these jazz education pioneers to pick their brains about how they got started doing what they do, how they developed the methods and materials that they created, and their thoughts on the state of jazz education and jazz music today. They were all more than happy to sit down and discuss their thoughts on jazz and jazz education - past, present, and future. Although the focus of the interviews was these gentlemen's contributions to jazz education through teaching, workshops, and publications, a number of other topics came up in the course of our discussion including their roles in starting programs at universities, race, gender, and popular music.

JERRY TOLSON: How and when did you get started teaching jazz?

JAMEY AEBERSOLD: It was probably when I was about 20 or 21 years old, and someone at IU [Indiana University] asked me if I would take over their private teaching in Seymour, Indiana at Silver Gardner's, no actually it was Johnny Otte's Music store in Seymour, and I told him yes. So I went down and started giving half hour lessons, and that was the beginning of it. That was after I had told everybody who would listen that I would never be a music educator because I felt that in order to educate you had to be able to play your instrument, which I felt not all the music education majors that I heard practicing were able to do very well. I guess I set a pretty high standard thinking that was the way everybody should be. Although if I had thought back on my high school directors, the two that I had, I never, ever heard them play an instrument. So [evidently] you could be a director without playing, but that didn't enter my mind. So I started teaching privately, and that's how I got started. Once I graduated from IU, I started teaching lessons over in my apartment [in New Albany, IN]. We started a little combo over there, and then we moved here in 1967. [Aebersold's current location on Aebersold Drive in New Albany]. We started running combos next door with Pat Harbison, 
Ken Sloan, David Lindhart, and I think John Goldsby. ${ }^{2}$ Various people came over, and that's kind of how it got started. I think about 1965 Ken Morris at the National Stage Band Camps asked me if I would like to work their big band camps and run sax sectionals for two hours in the morning and two hours in the afternoon. That was fun; I enjoyed it. That's how I got started there, and then they asked me if I would play records for the students because they didn't know the jazz musicians. Then they asked if I would run a combo after dinner for the better students, and that kind of led into the combo camps, which started in 1972. Actually, the first combo camp was in Provo, Utah at Brigham Young University. It was me, Jerry Coker, Rufus Reid, Dan Haerle, Charlie Craig on drums, and a guitar player that was from there.

DAVID BAKER: Well, like I say, nature abhors a vacuum, and wherever there is something missing, there is a place for you to be in to try to do something. I actually did my first teaching in 1955 with people like Julius Hemphill and the students at Lincoln University. But I didn't think much of it because there was no jazz involved. I mean, I taught the guys privately, but they were not allowed to study jazz as a part of their schooling. It was a black school, and jazz was not allowed in their formal study. In all formal senses, I began teaching after I went to Los Angeles with the Kenton Band. When I came back [to Indianapolis], there were a lot of kids who wanted to study: Freddie Hubbard, Larry Ridley, Jimmy Spaulding, "Killer" Ray Appleton, and Carlena Hampton, Slide's niece. I started teaching at home, and you know, at that time, it was a time when I would teach at home with my high school kids, and I would go to the homes of the people who were younger than that because I was teaching younger students, too. I went out to their house and taught for $\$ 1.50$ per hour. You know that was a long time ago. You're talking about the end of the 1950s and into the 1960s. By that time jazz had started to be on a level at [higher education] institutions. Jerry Coker was already an adjunct teacher, basically a glorified teaching assistant. He had already begun to teach some courses in arranging and improvisation.

JERRY TOLSON: This was at IU (Indiana University)?

DAVID BAKER: Yes, at IU. So when he decided to go to Texas I think it was, he put my name forward for the job. That particular dean at the time was not that enthusiastic about having, I think, a black person in that position. Not only that, I was way down on the list of people to be considered for the position. Because of Jerry, who insisted he wouldn't give the dean any other

${ }^{2}$ Jazz musicians on trumpet, trumpet, piano, and bass, respectively who hail from this geographic area. 
name but mine, he was responsible for my being at Indiana. And I had pretty much carte blanche to put together a program. That's why they brought me there to put together a program. They didn't give me the manpower, nor did they give me the facilities and the people to do this. What happened is that I continued to teach the course in improvisation and the course in arranging, but I understood, particularly as a black person coming out of non-traditional schools, that you can't have a jazz program without teaching a history course. So I put together a jazz history course, but they wouldn't let me teach that course on my own because I didn't have a history degree, which is ridiculous. So they assigned Austin Caswell, Sarah's father ${ }^{3}$, and we were good friends. So we team taught the course the first year. And more and more I realized that there had to be more than one class, a jazz class and a class that dealt with traditional folk music of black people. Whether it was James Brown or Aretha Franklin, there was just no time to do that in a one-semester course on jazz. So I began to try to put the course together, and I drew up a potential curriculum. It took probably ten years for all the pieces to fall into place. So I put together two improvisation classes, an arranging class and a composition class, but more importantly, two history classes. One was called "History of Soul in Jazz," and the other one was called just "Jazz History." Between that and trying to have the bands, I was able to put the program together. I was not teaching privately at the time because that was basically under another rubric. By 1963, they were not willing still to accept it [jazz] as a curriculum at the school. So in $1964 \mathrm{I}$ talked to that dean, and the director of concert bands at the time said, "As long as I am here, jazz will never be a major ensemble." The next year he was gone, and they instituted the jazz degree program in 1966.

JERRY COKER: I got started back in 1955 in San Antonio, just yesterday (chuckles), when a couple of students who wanted to study jazz were referred to me by my wife, Patty. I have to say I was a little nervous and terrified because I thought that I did not want to be responsible for someone else's learning especially if I am going to have to invent all the stuff they are going to work on. So after I got over that, I took about a week to prepare, and during that time I sat down and wrote down everything that I thought I had ever learned in my own quest for playing. I ended up with a very long list. Then I went back over the list and started crossing things off, eliminating things that I had learned, but not found meaningful or useful. Then I put them into a logical order, a sequence. I made an outline and wrote out a few starter type

\footnotetext{
${ }^{3}$ Sarah Caswell, a native of Bloomington, IN, is a New York based jazz violinist who has been hailed by David Baker as a "brilliant world-class violinist ... one of the very best of the present generation of emerging young jazz stars."
} 
patterns and things. So the lessons worked out well. In fact, they got me my first teaching gig at Sam Houston State University in Huntsville because the head of the department there played a gig with the two of these guys and saw how much they had improved in a very short time. He decided that the improvement was on the basis of what I had taught them. Well, we moved around the country a lot of places, and the outline kept getting longer and longer and more spread out. I began duplicating it and giving it to my private students. I had about thirty-two students at the time. Then when I took the job at Sam Houston, I was working on my Master's degree and needed a topic for my thesis. That's when Bill Lee (former Dean at Sam Houston State) suggested that I do it on improvisation. He said, "that's your field; it's what you've gotten into and gotten results." So that's what my Master's thesis was on.

RUFUS REID: I really didn't want to teach, but I started out teaching oneon-one in Chicago with 4-5 students per week. My first organized teaching situation was in North Dakota. I met Jamey while I was playing with Eddie Harris and did my first workshop at that time. I love to teach. That's why I do workshops. Players who want to make a livelihood and sustain themselves have to balance keeping up their chops and making a living. For me it means that I teach what I do.

DAN HAERLE: When I went to grad school at North Texas, I was studying theory and composition, but I was very involved with the jazz program, playing in the 1:00 band, directing a lab band, teaching improvisation, and doing arrangements. That was great, and I enjoyed it, but that wasn't what I was going to do. I was going to be a composer and write all kinds of chamber music and orchestral music. My first job was teaching theory and composition at Kansas State, but while I was there, Leon Breeden (Director of the program at North Texas from 1959-1981) recommended me for a position at Monterey Peninsula College where Jerry Coker had actually taught. They had not had a jazz person there for a while, but since they were in the shadow of the Monterey Jazz Festival, they wanted to boost up the jazz program again. At first, the position was classical theory and classical piano with a little bit of jazz. I had a jazz band, improvisation class, and a jazz appreciation class, but it was mostly other stuff. That was OK, but then Jerry Coker called and wanted me to come and teach at Miami and concentrate mostly in jazz. This meant getting in deeper with jazz. There, everything I did was in jazz except for one theory class, which meant I was a member of the theory faculty teaching form and analysis or orchestration. So that was almost all jazz. After teaching there a couple of years, I quit and went to New York, but I realized that I liked teaching and wanted to get back into it if the right 
situation came along. That's how I wound up at Arizona State, which was my first full time jazz position. There, I was sort of the co-coordinator of the program, which was enjoyable as we were able to develop the program. Then Leon called about a position at North Texas, but I wasn't sure that I was interested because I was happy, had put down roots, and was pleased about what was happening with the program. He was persistent, however, and finally convinced me to look at the position. I figured that I owed him that much because he had recommended me for most of the positions that I have had. So after hearing the students, I decided that this was where I needed to be, and that's how I wound up there for quite a while. (He recently retired after almost 30 years at North Texas).

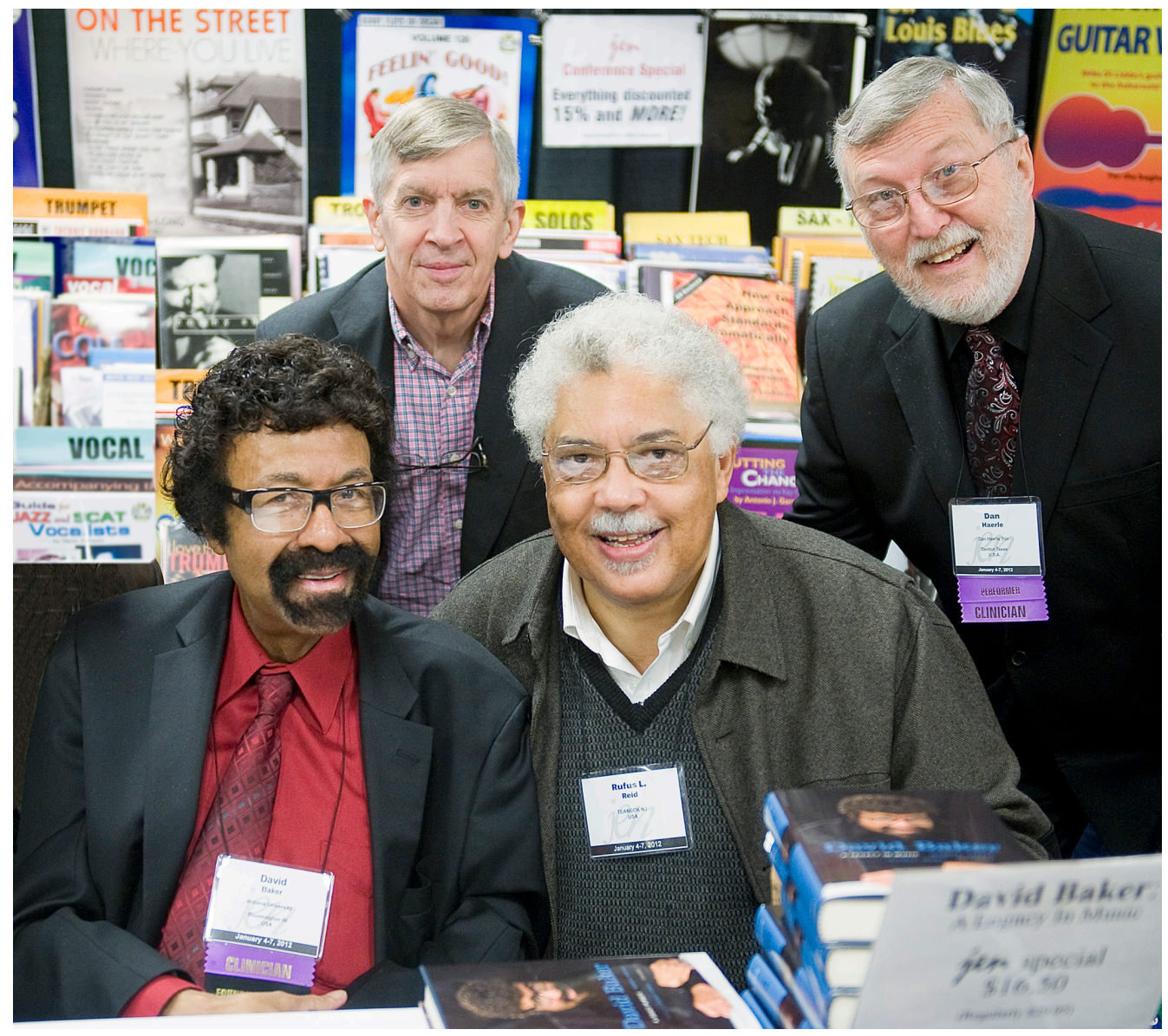

Figure 1. From left to right: David Baker, Jamey Aebersold, Rufus Reid, Dan Haerle; Jazz Education Network Conference, Louisville, Jan. 2012. Photo: Ed Berger. 
JERRY TOLSON: What kinds of materials did you use in the early days when you first started teaching jazz, and how did you get started doing educational publications?

DAVID BAKER: It really gets down to this. At the beginning of all this, I think Coker's book was in '61 and mine was in '63. So our books were really kind of the bedrock on which most of the method books were built. And we used to say...Coker would say when I see and go in and look at the index of a new jazz book, if I don't see both of our names in it, I know they stole from whoever's name they did not have. And if I don't see either of our names, then I know they stole the whole thing. And so, consequently there is some merit to that.

JERRY COKER: Because of the improvisation classes I was teaching there at Sam Houston, I began cranking out copies of the handout I had created and giving it to each student. One of them gave it to his high school bandmaster who had it sitting on his desk. A representative from Prentice Hall came in and saw it and ask[ed] what it was. The representative read it, and that was the birth of "Improvising Jazz." I had to completely rewrite it, but they (the publisher) said that was the kind of thing they were looking for. That was how the first book came along, and now I have seventeen published books on jazz and improvisation. It was a slow kind of process with a little bit here and a little bit there, but it has been a very productive and happy time.

RuFus REID: I started using Ray Brown's bass book, but I also started writing etudes for my students. Then, I would write things after gigs to a point when I put everything into a book that I self published called The Evolving Bassist. I still own and publish the book today. (One of the premier bass method books on the market).

DAN HAERLE: I have always felt that I have been lucky to be in the right place at the right time. Over a number of years I had developed all sorts of handouts for students in classes. So I had all this stuff that I was always duplicating and handing out for classes. When I left Miami, Jamey (Aebersold) talked to me and said he knew this guy who wanted to publish jazz books. He told me that I should show him my stuff, and my reply was, "What stuff?" Jamey said, "You've got a bunch of handouts," but nothing was really organized, and I didn't think anyone would be interested in publishing it. However, this was in the early to mid 1970s when jazz education was just beginning to blossom, and people were hungry for publications. So I had two things, one of which was all this stuff on piano, which became the Jazz Rock Voicings book. 
JERRY TOLSON: Which I still have and recommend today as required reading for my students.

DAN HAERLE: Well, you know that book is kind of funny in that it is just kind of a collection of stuff, and it is not really very well organized or anything. But I had all this stuff that was the kind of stuff that I was looking for when I was younger. I thought maybe someone would like that [information], so the publisher said, "That's great. Let's publish that." Then he asked if I had anything else. To which I replied that I had my scale notebook that I practiced out of. Asked what it was all about, I showed him that I had all the scales written out in all the keys in treble and bass clef. The publisher said, "Great. Let's put that out, too!" So I said OK, and we put both those books out. I was surprised the scale book did much better then I thought it would. I discovered a lot of people wanted [a book] organized so they could practice out of it. That was very gratifying. People would ask me about the scale book, and I would tell them that they could buy the book or just write their own. By the time they would write all the scales out, they would know them then. Those were the first two, Jazz Rock Voicings and Scales for Jazz Improvisation. After that the others kind of came about out of necessity for this or that kind of class.

When I got to North Texas in the late 70s, my first assignment was to teach a jazz theory class and develop the course, which I did. For a year it was an experimental course. It didn't have an actual course number or anything yet. I was kind of shaping it and getting a sense of what we could do and what we should do, and I was developing lots of handouts and materials and so forth. But it was kind of a pain in the neck to keep duplicating the materials and handing them out. In the early days I would put together packets and put them in the bookstore for the kids to buy essentially for the expense of copying. I told my publisher that I had this jazz theory book, and ... we put that out. Then I had all my stuff for my piano classes, so we published the jazz improvisation for keyboard books. I had my foot in the door with those first two books, and they did well enough that the publisher was open to doing more, in fact was looking for more. And then, as the software became involved and the computers had more power, we got into desktop publishing. So then I did The Jazz Sound, where not only did I write the book, but I also laid it out. I tried to make things look attractive as well as communicating information.

JAMEY AEBERSOLD: Well, I started working on the play-a-longs in 1966, and the first one came out in 1967. I was doing a Ken Morris big band camp in 
Stoerrs, CT, rooming at the time with (bassist) Ron Carter. ${ }^{4}$ At the end of the week, I was giving a lesson to two tenor saxophone players, playing piano and walking bass lines, listening to them solo and making comments. One of them asked me to make a reel-to-reel tape of the accompaniment so that they would have something to practice with when they got home. Instead of making a tape, I made a record with piano, bass, and drums. Then it dawned on me that if I sold the record, some people would get a hold of it and complain because there was no melody. So I wrote a book, which took forever. That's how I got started. Of course, before he even asked me about tapes, as a kid, I had made some play-a-long tapes on my father's DuKane reel-to-reel recorder to take to school with me. I used my mom's Hammond organ. I don't remember if it was a B-3 or not, but I remember walking the bass lines and playing the chords with my Seth Thomas (metronome) going. I think I had Lazy Bird and a blues on it. I probably still have that tape somewhere. I would practice to that tape in my practice room at IU because there really wasn't anything else to practice with.

JERRY TOLSON: Do you notice a difference between players who have learned using the play-alongs versus those who have learned in some other manner?

JAMEY AEBERSOLD: There is going to be a noticeable difference for sure. The ones that play with the play-a-longs are going to understand form, and they are going to understand, whether they can do it or not, that this chord represents this scale and arpeggio. Then you take that information and couple that with your imagination, and it is supposed to give you a better solo. Whether it does or not is still up to the individual. They have the left side of their brain, which is the theoretical, thinking side. Then they have the creative right side of the brain. The way you marry those together sometimes takes a long time for some people. But then the other people who play just by ear, so to speak, they can get lost, they can stop at the wrong time, or they can not hear the changes unless they put a lot of practice in. I still think that one of the best ways to learn how to play is by listening to records and imitating the masters. Self-transcribing, transcribe yourself, transcribe them, analyze it as much as you can, and that should make you a better player. Listening, though, is so important. If they have just intellectualized, it only gets you so far. You will know a lot, but that does not necessarily mean you will be able to make a lot of music. And making music is the main thing.

\footnotetext{
${ }^{4}$ Ken Morris ran the National Stage Band Camps throughout the '60s and into the '70s. Camps were held in sites all around the country.
} 
JERRY TOLSON: There are some people who criticize your play-a-longs for that reason. What do you say to them?

JAMEY AEBERSOLD: Oh yeah. I mean those people have taken the play-along so far. I mean, not the ones who criticize, but the ones who sound like a machine or sound like they have been playing with a play-a-long record and not using their imagination. Sorry! They sound like they are not using their imagination. Now I also think that those who play that way aren't used to listening to the jazzers and picking things up. I can tell it in their playing, because it doesn't come across. It does not come across! To me, listening to records has always fueled my imagination. I am anxious to practice and play. They give me new ideas, and they give me new thoughts, but I don't think that has always registered with the students. For some reason a lot of them have not fallen in love with listening, I don't think.

JERRY TOLSON: Well do you think that maybe it's because people who are trying to be self-taught don't know that it is the connection between the playa-long and the listening.

JAMEY AEBERSOLD: Oh, probably so. Maybe they think of the play-along just as a separate entity to play with somebody, maybe to run scales and arpeggios. They don't think of the end result, which is that every time you put on a play-a-long record and you are going to solo, you probably should be playing something different. It is a new day, you know, and your imagination should create new ideas. Every time you play, if you are improvising, it should be different even if it is the blues on volume one, track seven. And that to me is based on listening to records and things. Whenever I hear those people play, I hear them repeating themselves sometimes, yes, with the same phrasing, same articulation. But it seems as if each time they play, and this is an important thing, it is as if they have just discovered it. It sounds fresh every time even they are going up the $\mathrm{C}$ major scale for the fifteenth time. And that is a key thing that young improvisers need to understand is that you don't have to try to play something brand, brand new every time or you are not playing jazz. It's the way you play, what you play, and how you play it that makes a difference.

JERRY TOLSON: With all the publications out there, yours and others, what is your opinion of the jazz education materials that are available today? How do you think they are impacting the teaching of jazz?

JAMEY AEBERSOLD: I don't think they are a hindrance because the only time that would be the case is when someone buys a book, pays a lot of money, and isn't getting anything out of it and can't return it. I think every book that 
we sell probably has something valuable in it. I said a long time ago, since I am selling books, that I didn't need to take on books that are duplicating other information in other books I was already selling, that are overpriced, or that are giving out wrong information. I am not for disseminating poor, bad, or misinformation, period. Good information, yes, I am interested in that. My name is on the company, so that makes me responsible for what goes out there.

RUFUS REID: The impact of printed materials has been to bring the jazz world together. Performers and audiences are becoming more educated.

JERRY COKER: I think it's good that there are a lot of people writing, don't get me wrong, but I'm not sure what their motivations are. In some cases, they may want to just get their name out there, or maybe the head of their department thinks they need to get something published. But there have been some very good things that I have had nothing to do with that have been written by other people, and I am very gratified by that. However, I am a little disturbed when somebody comes up to me and says, "Oh, you're Jerry Coker. I have your book." Then when I say which one, they answer, "Is there more than one?" That kind of thing means the word isn't getting out very well. Then with regard to the way things are being handled on computers now with the piracy and the plagiarism that goes on, those aspects are a little disheartening. Nevertheless, all of this stuff that has been written has at least given students an opportunity to learn something that was not around when I was their age. There were no books, no systems, no outlines or anything. I was blessed to have several very good teachers who knew how to do it. They were just good in person-to-person situations playing with you and helping you learn what you needed to know. When I was on the Woody Herman band, young people used to come up to me after concerts and gigs and engage me in conversation wanting to know things, and I could not refuse them because I used to do the same thing. In the absence of books and university systems and teachers, it was the logical way.

DAN HAERle: What I've seen is more players coming with better preparation earlier. I mean there are some good educators around in high schools that are getting these kids playing, improvising, learning theory, and so on. So they are arriving in college much better prepared than they did before. They have definite, distinct advantages because they are getting an earlier start. What they often don't get is the concept because they haven't done enough listening. But the materials have definitely helped because the bright kid can understand what this is and what that is and go to work on it. I think they have definitely had a positive effect.

DAVID BAKER: I've never lost sight of the fact that it is "his' story. And I look at all the good books out there. Eileen Southern probably wrote the first 
really comprehensive book. ${ }^{5}$ But there have been some other books [that have] come out with some credibility issues. Some are better than others. You know Bill Banfield (Berklee) and I are doing a book with Quincy (Jones) because Quincy has the muscle to make the people talk.

JERRY TOLSON: I didn't know you were working on a book.

DAVID BAKER: We have been working on it for like five or six years. What we are doing is looking for the roots of popular music and how they link up with all other popular music. So that we see at a glance that the people who are playing James Brown are the same people who play what Minnie Pearl does. ${ }^{6}$ Those roots pretty much have been the things that have provided the background. That's why you very rarely ever find someone from the Grand Old Opry teaching in a college, but they should! Man, it's American music. And jazz music is that as well, and teachers forget that, and this is where it is our task to remind them that it's something different. America is the only country in the Western Civilization where they have no sense of who they are. That's why they feel like they have to keep genuflecting at the shrine of European culture because they don't know anything else. And that just disturbs me to no end.

JERRY TOLSON: What are your thoughts on the number of schools offering jazz degrees and the number of students graduating with jazz studies degrees?

JAMEY AEBERSOLD: I think the number of programs is good if the teacher knows what he is doing.

I think every jazz studies person should come to our camp because I know they will go back with ideas and information that they can use to help them be a better teacher. I think the college programs are fine if the person running the program and the guys doing the teaching know what they are talking about. I

\footnotetext{
${ }^{5}$ Eileen Southern, The Music of Black Americans: A History, 3rd Edition (New York: W.W. Norton \& Co, 1997).

${ }^{6} \mathrm{~A}$ result of the shared genealogy of gospel in both soul and country music in the south where strong religious beliefs made gospel highly influential to both blacks and whites, and where musical miscegenation was, ironically, more likely to take place than in other areas of America. Although white gospel and black gospel styles began life with major stylistic differences, they had merged somewhat by the 1950s, and, added to that fact, whites were, by then, hearing recorded black gospel at a much greater frequency than ever before. The result was country gospel traditions seeping into soul music. Robert Fontenot, "Country Soul" Oldies Music Glossary, accessed October 2, 2013, http://oldies.about.com/od/soulmotown/g/countrysoul.htm.
} 
think the jazz programs have a lot to offer. The number of students graduating with degrees and no place to play has always been a problem. Back thirty or forty years ago, I can remember talking about this with David (Baker) and Pepper Adams after a concert at Millikin University, thinking what are we going to do if we get all these people playing and they graduate and there are not enough jobs for them. It was a hard thing back then, and it's worse now. The best ones will survive. They will play jazz occasionally or move to an area where they can occasionally play. They usually end up teaching because they love what they do, and they want to show it to other people. Becoming really successful and making a lot of money at it - don't plan on it. It's like that Dave Brubeck thing. Don't go into it to make money and become famous; go into playing jazz because you can't live without it, or something like that is what he said. I've got it quoted somewhere. I always thought that it was such a great quote because it is so true. And it's worse now than ever. We definitely need the Obama Jazz Stimulus Package (chuckles).

JERRY COKER: There are an awful lot of them, some better than others. There are enough good ones to take care of the numbers that really want to learn the music. It is very hard to do that kind of a program. At Miami, when I first went there, I asked what courses I was supposed to teach. Bill Lee, who was the dean at the time, told me that I was the expert and that I needed to design it myself. I was worried about getting an entire four-year program and later a Master's program logically sequenced and everything. I was so concerned that we get it right that after each semester of the initial courses, I met with the students to get their feedback. Initially there were a number of suggestions for changes, additions, and deletions, but after five years, the feedback indicated that there were no problems. So I figured we had it right, but it was a long process and very hard to do. I don't take credit for the success, however, because it was a joint effort of the students, grad assistants, and our experience. Soon thereafter, about twenty or thirty universities wrote to inquire about the curriculum and how to work with it to set up their own programs. Not all have been as successful, as there are some programs that are stronger than others. When I moved to Knoxville (TN), I instituted the exact same program because I knew it was a winner. When it was time to add the graduate program, a colleague asked me if we had contacted other universities about how they are setting up their Master's programs. At that point, I had to let him know that I had invented the University of Miami program many years before and had a pretty good idea of what should be included in the program.

JERrY TOLSON: So was that program at Miami the first Master's program? 
JERRY COKER: Yes, it was the very first one. To my way of thinking, it was also the first really thorough four-year program. When Dan Haerle left Miami (We both left in the same year) and went to Arizona State, he used the Miami program as a model. And even though North Texas had had a program for a long time, it was comprised almost entirely of ensembles, jazz history, arranging and composition. There were no improvisation courses until Dan went there, which was a long time after the program started.

JERRY TOLSON: How do you think the presence of so many college programs is impacting today's players? Has it made them better? I hear so many that sound the same. They practice the same exercises and the same licks.

JERRY COKER: I think it goes in both directions. I really do. I think for some of them it is exactly what gave them the information and the drive to succeed and excel, and we have seen a lot of them at these summer camps. On the other hand, I think some of them have tried to sort of do it from a do-ityourself steps one to ten kind of system where you learn this pattern and that pattern and play this way or that, and it's kind of limiting. However, as for how much of that is the individual and how much is in the system that they were brought up in, I don't know. I do a lot of private teaching now, about 16-18 private students, because you know I don't teach at the university any more. I find that each one of them is very different, and I can't approach them all the same way. When you teach in a university course with 8-12 people coming in the first day of class, you have a syllabus and a textbook, and you try to cover certain material and lay out the assignments accordingly. If you do that, you feel like you have done what you were supposed to do. But even in that situation, you have 8,10 , or 12 people in there, who all function in different ways, and I didn't know that until I started doing a heavy load of private teaching. That's when you discover how there are four basic ways that they learn, and that's how you can end up with some of the ones who just play patterns. You can either approach it through the ear, through the mind, through the hands, ah, or ... I'm leaving out one.

JERRY TOLSON : Visual?

JERRY COKER: Yes. Visual, because of seeing stuff in the music, and I find that to be the weakest one. I try to remove the music from in front of them as quickly as possible so that they can internalize things and not be reading things all the time. You want them to know it. But there are students that used to come up to me when I first came to the university and apologize for only being 
able to play by ear. I would always tell them great, that's wonderful, I can teach you the theory of it in the matter of a few weeks, but I can't teach you to have good ears in a few weeks. So the hardest part was already done. Besides music is sound, and as such, as my old teacher, who was a composition teacher, used to tell me, what does not sound well should not be written. He would repeat that over and over as an axiom, and then in later years, I realized that should apply to improvisation. Music is communicated by sound, not by what it looks like or what you think about it. It's what it sounds like, and if it doesn't sound good, who cares. I have had students that have come up to me in the past who were into the serial music thing and show me the score, and say see what I did here, and I would say just play it. Let me hear it. The proof is in the pudding, what you hear with your ears. The point is that there are different ways to approach music, and how we do it in the university is often not the best way.

JERRY TOLSON: What do you see in the future of jazz and jazz education?

DAN HAERLE: I think it is just like classical art music. It is the refuge for the music. Universities and colleges are going to keep jazz and classical music alive because they are not popular music (styles), and they never will be. They are struggling, and they are scuffling. Musicians can't make a living playing jazz most of the time, but they can't make a living playing in an orchestra [either]. Orchestras are really struggling, having to get all kinds of grants, extra donations, and everything. I think the universities have sort of taken over the place of the courts. You know back in the days when Mozart, or whoever, was a court musician, they were the patrons. They were what kept the musicians supported. Now it's the universities, and thank God for that. So, I think the fact that there has been a lot of growth, at least to the point where virtually every college has at least a jazz band or a couple of jazz courses, if not a degree, I think that that is encouraging.

DAVID BAKER: Jazz is American music and it is up to us as teachers to make sure that that fact is not forgotten. We have been very fortunate to have good teachers, but it is my goal in the next ten years to make sure we continue to have people in place to teach this music. We have to make sure that students know not only about black jazz musicians, but others in the classical realm as well as popular music.

JERRY COKER: That is a toughie. We have a problem that we haven't discussed here. Even though there are a lot of students who come to jazz camps, nevertheless, the music is declining in our society. It is not the enormously popular music that it was before, and it has been replaced by a 
music that requires virtually no thought and little of anything else except for maybe a little dancing.

\section{JERRY TOLSON: You mean booty shaking?}

JERRY COKER: Right! Right! That I see as a problem for the future. In fact, I tell my students that if jazz were to suddenly become massively unpopular and go away, which may be the direction things are headed, the blues would still survive, because people still love it and will go listen to it. The blues does not belong to jazz. Jazz uses the blues, but blues people do nothing but sing and play the blues. They don't care about Giant Steps and Billy Strayhorn tunes, or whatever. They do the blues. They sing it, and they play it. They do very well, have a good following and make a lot of records. They have a lot of festivals of the music, and I don't think that that music is ever going to die out, but it is possible that jazz could. The ones that are trained in jazz have to be able to go out and make a living. Well, the road bands are gone, and most of the name bands are gone. The cities are crowded with people that are all scrapping for the same gigs and all. The only thing that gives me heart is that whenever a jazz program starts up in a university town, strangely the town goes from not having any jazz clubs, or maybe one, to having maybe five or six of them. Students go around knocking on doors saying let us play even a Sunday afternoon session. The students' aggressiveness actually causes things to open up a little bit. But I still can't help noticing that the large portion of the audience that loves jazz, or that I see in clubs now, is my age or slightly younger. I do not see very many really young kids unless they, themselves, are studying the music. So I don't know. I worry about the future of it. The summer camps give me heart every year. I walk away thinking where are they coming from and how could they be developing in this present day society. And how could they actually still be attracted to something like this, and how do they even find out about it. I'm amazed, and I go away from the camps refreshed and feeling like maybe it will be around, that maybe there is hope. Of course, hearing some really extraordinary level players also gives me heart because I think that is one of the things that is going to help keep it popular enough to be around. The extraordinarily good young players that you just can't deny, that no matter what kind of music you play, you just have to sit back and say, "Wow, that guy really plays." Maybe there is a chance that it will be rediscovered.

RUFUS REID: In the $21^{\text {st }}$ century jazz is in a better place. The world has more access to the music because of the Internet. Distribution is the greatest challenge. 
DAVID BAKER: I wish that we were able to attract more black students. However, I am not sure, given all the things in our background, even with Dr. King's eloquent defense of jazz, I am surprised that we don't get any more. ${ }^{7}$ However, a lot of people don't take it as seriously as they should. One of the things that remains constant is that we don't have as many blacks involved. ${ }^{8}$ That's why I continue to teach the "Soul in Jazz" class because this is where they hear James Brown, Aretha Franklin, and Thomas A Dorsey. They have got to know who we are and where we came from. The people teaching the courses always teach from the vantage point of what they know and what they have experienced. And consequently we have kids coming through who have never heard signature works such as the 1953 version of "Walkin" with Percy Heath on bass, Kenny Clark on drums, Horace Silver on piano, Lucky Thompson on tenor, Miles Davis on trumpet, and J.J. Johnson on trombone, which represents the essence of hard bop. That's like saying I have been taking classical history, and I don't know Brahms or Bartok. That's not acceptable at all. Fortunately, I have enough cachet at IU with more than 45 years teaching there to demand certain things. I'm getting there, but I still have trouble attracting black students.

JERRY TOLSON: Many of our students are too busy wanting to be Jay-Z, Ice-T, or Ice Cube.

DAVID BAKER: Ice-T, or whatever Ices. And I'm not sure, but I think it is incumbent on us, those of us who are in academic positions to preserve and pass on the legacy before we retire. The reality is that it seems to me that jazz now has proliferated to a point where it's unthinkable that even high schools would not have a jazz program, and I understand that it's also a monetary concern, because if you can get one person who can teach an ensemble that's got twenty in it, they are better off, in their minds, teaching that than having a

${ }^{7}$ Dr. Martin Luther King, Jr.'s support of jazz is usually attributed to a speech given at the 1964 Berlin Jazz Festival, though King did not attend the festival. David Demsey and Bruce Jackson have shown that King was asked to share his thoughts as a Foreword for the festival's printed program. The full text of Dr. King's comments can be accessed at http://wclk.com/drmartin-luther-king-jr-importance-jazz.

${ }^{8}$ The audience for jazz is overwhelmingly white making up roughly $80 \%$ of those attending concerts. But rates of participation for African-Americans are consistently higher than those for whites. African-Americans account for only $11 \%$ of the adult population, but make up $17 \%$ of those attending concerts and $20 \%$ of those listening to jazz recordings. Roughly $25 \%$ of the most frequent concert-goers, and a full third (34\%) of those who "like jazz best," are black. From Scott DeVeaux (1999), "Jazz in America: Who's Listening," Carson, CA: Seven Locks Press. Based on data from the 1992 Survey of Public Participation in the Arts sponsored by the National Endowment for the Arts. 
one-to-one teacher where they have to pay one person to teach all the different things. For me, my battle has been to make sure that within another ten or so years we see more black faces teaching.

DAN HAERLE: We are seeing more support of the music, or at least more concern about preserving it and helping it grow. I think that's a good sign. I see the future in a couple of different places. We have seen this growth in senior activity (especially at camps), people who have come back to their instruments after many years and are enjoying their senior years pursuing their love of the music. So we have that element. Then we still have young kids who want to get information that they either don't understand or can't get elsewhere. They want to rub elbows with experienced jazz musicians. So I think that jazz camps will continue to grow. At one point I thought that camps would become obsolete much like the stage band camps, largely because all the colleges had stage bands and most high schools have a stage band, too. So as colleges and high schools get combos and so forth, maybe Jamey's type of camp will not be needed anymore. But they are still out there and are still viable. As jazz education keeps growing in the schools, maybe we won't need the type of experience that camps provide. I think we are also going to see more growth at the younger ages. In the last several years, I have been hearing middle school bands that are doing amazing things, sounding great. I think there's a point of diminishing returns there, as I don't know how young you can get kids going in jazz. But you see examples of this on YouTube. Occasionally I will see some young player like this thirteen-year-old pianist [Gadi Lehavi] playing with Dave Liebman in Lebanon or this young alto sax guy from Italy. So you may see more instances of that, and this may be an area that grows.

\section{CONCLUSION}

To be sure, there are many approaches to learning the jazz language and how to improvise. Other significant contributors to the lexicon of jazz education include John LaPorta and Jack Petersen, who developed the program at Berklee College of Music using the Greek modes to teach chord-scale relationships; Bill Dobbins, who helped develop the program at Eastman School of Music; Barry Harris, whose approach using diminished chords has been replicated numerous times; and George Russell, who wrote the seminal text The Lydian Chromatic Concept. David Liebman, whose text A Chromatic Approach to Jazz Harmony and Melody opened new inroads into creative approaches to improvisation also founded the International Association of Schools of Jazz (IASJ), an organization dedicated to networking educators and students from international jazz schools. There are many approaches to 
developing skill in jazz improvisation. In fact, some would argue that it is not desirable to have a comprehensive methodical approach to improvisation. However, if you subscribe to the philosophy that jazz is a language, it stands to reason that there is a coherent vocabulary and language that comprises the genre. Jazz trumpeter, Clark Terry, is often quoted as saying the secret to the art of jazz can be summed up in three words, "Imitate, assimilate, and innovate."

While this simple statement captures the essence of learning the language of jazz, the reality and practical steps that the aspiring player must go through involve many hours of study, practice, listening, transcribing, and trial and error. Any method or approach that helps players achieve their goals is worthy. Thus, whether it is a written publication, YouTube video, educational workshop, jam session, or structured program of study at an educational institution, there are many ways to achieve competency as a jazz performer. The names Aebersold, Baker, Coker, Haerle, and Reid are part of the royalty of instruction in this musical genre. The opportunity to garner insights into their history and motivation is beneficial to anyone involved in the music. Mr. Aebersold probably best summarized the impact that his work and the work of others have had on the direction of the music.

JERRY TOLSON: What do you think is your legacy regarding jazz education? Do you ever think about it?

JAMEY AEBERSOLD: No, not really. I'm just who I am doing what I do. I wish I had more free time to go through all my shelves and tapes and meet what I call old friends. It could be a lick, a pattern, somebody's name, or maybe a letter that somebody wrote about something. I would love that. I haven't thought much about the legacy because I am too busy being here today.

With this statement, maybe Aebersold has hit upon the secret to these gentlemen's success and impact on jazz education for over 50 years. They are continuing to do their thing, working daily with students of all ages eager to learn this musical style. Thus, they are too busy doing what they do to worry about their impact or legacy. They continue to impact the field through their publications, recordings, play-a-longs, workshops, and camps. Without a doubt their legacy is forever etched in the pages of jazz education history.

ABOUT THE CONTRIBUTORS

9 "Clark Terry Quotes," http://www.jazzquotations.com/2010/05/clark-terry-quotes_25.html. 
JAMEY AEBERSOLD is an internationally-known saxophonist and authority on jazz education and improvisation, and has developed a series of Play-A-Longs (book and cd sets (now numbering almost 130 volumes) as well as various other supplemental aids for the development of improvisational skills. The Aebersold book and recording sets allow a musician the opportunity to practice and improvise with well-known jazz personalities at home as well as in the classroom. This concept has been responsible for changing the practice habits of thousands of musicians around the world. Jamey was one of the first to encourage small group classes that concentrate on jazz improvisation, and he is the director of the Summer Jazz Workshops, which have been in existence for over 40 years. Aebersold was born in 1939, in New Albany, Indiana. He attended college at Indiana University and graduated in 1962 with a Masters Degree in Saxophone. He was awarded an Honorary Doctorate of Music by Indiana University in 1992. He also plays piano, bass, and banjo. In 1989, the International Association of Jazz Educators inducted Jamey into their Hall of Fame. In 2014 he received the A.B. Spellman American Jazz Master Award for Jazz Advocacy from the National Endowment for the Arts. Aebersold is a strong proponent of the philosophy that improvisation is something all people can do, and his clinics and lectures focus on demonstrating how the creative and spontaneous nature of each person can be brought to light. These weeklong Summer Jazz Workshops are having a profound effect on musical communities around the world. The workshops have traveled to Australia, New Zealand, Germany, England, Scotland, Denmark, and Canada. Every summer there are at least two, week-long workshops in the U.S. These camps employ many of the finest player/teachers in jazz and are open to any serious jazz student regardless of ability or age. In 2007, Jamey was awarded the Indiana Governor's Arts Award by Mitch Daniels, the Governor of Indiana. In 1987, CBS' "Sunday Morning" with Charles Kuralt and Billie Taylor featured Jamey with the Summer Jazz Workshops in a jazz educational segment. Jamey has taught at three colleges and universities in the Louisville, Kentucky area and has made guest appearances in dozens of cities around the world. Jamey has been a driving force in America's native art form, jazz, and continues to kindle the fires of musical imagination in those with whom he comes in contact. ${ }^{10}$

DAVID BAKER was born in 1931 in Indianapolis, Indiana. He is Distinguished

\footnotetext{
10 "Jamey Aebersold Biography," Jazzbooks.com accessed October 2, 2013 http://www.jazzbooks.com/mm5/merchant.mvc?Screen=JBIO.
} 
Professor of Music and Chairman of the Jazz Department at the Indiana University School of Music in Bloomington, Indiana, as well as conductor and artistic director of the Smithsonian Jazz Masterworks Orchestra. A virtuoso performer on multiple instruments and top in his field in several disciplines, Mr. Baker has taught and performed throughout the USA, Canada, Europe, Scandinavia, Australia, New Zealand and Japan.

Baker received both bachelor's and master's degrees in music education from Indiana University and has studied with a wide range of master teachers, performers and composers including J.J. Johnson, Bobby Brookmeyer, Janos Starker, George Russell, William Russo, Bernard Heiden, and Gunther Schuller, among others. A 1973 Pulitzer Prize nominee, Mr. Baker was nominated for a Grammy Award in 1979, and has been honored three times by Down Beat magazine -- as a trombonist, for lifetime achievement, and as the third inductee to their Jazz Education Hall of Fame. Mr. Baker has received numerous awards, including the National Association of Jazz Educators Hall of Fame Award (1981), President's Award for Distinguished Teaching from Indiana University (1986), the Arts Midwest Jazz Masters Award (1990), the Governor's Arts Award of the State of Indiana (1991), the Indiana Historical Society's Living Legend Award (2001), the James Smithson Medal from the Smithsonian Institution (2002), the American Jazz Masters Award from the National Endowment for the Arts (2000), and an Emmy Award (2003) for his musical score for the PBS documentary For Gold and Glory. He has received honorary doctorates from Wabash College, Oberlin College, and the New England Conservatory of Music. In 2007 he was honored by The John F. Kennedy Center for the Performing Arts with their Living Jazz Legend Award. He has written more than 2,000 compositions, including jazz and symphonic works, chamber music, and ballet and film scores. He currently serves as senior consultant for music programs for the Smithsonian Institution. He has served a number of times on the Pulitzer Prize Music Jury and is Chair of the Jazz Faculty of the Steans Institute for Young Artists at the Ravinia Festival in Chicago, IL. He has more than 65 recordings, 60 books, and 400 articles to his credit. ${ }^{11}$

JERRY COKER who was born in 1932 in South Bend, IN, is a highly respected instructor, theorist, and author, whose early career was spent playing in such big bands as Woody Herman's. He interrupted his studies at Indiana

11 "Biography," The Official Website of Dr. David N. Baker, accessed October 2, 2013, http://www.davidbakermusic.org/bio.php. 
University to join Herman in late 1953, then toured with him until the summer of 1954. He made some recordings in Paris and San Francisco as a leader, and as a sideman with Mel Lewis in the late '50s, then became a freelance player on the West Coast. Coker had a short stint with Stan Kenton, then began an involvement with college bands and jazz programs in the '60s that led to him holding teaching posts at various colleges and universities. Coker began his teaching career at Sam Houston State University (1958-1962) and taught at Monterey Peninsula College (1962-1964), Indiana University (1964-1966), the University of Miami (1966-1973), Pembroke State University (1973-1974), and Duke University (1974-1975), before going to the University of Tennessee as a Professor of Music in 1975. Coker has written 12 seminal jazz education books. His first book, Improvising Jazz, was published in 1964, and was the first comprehensive study by a jazz educator. In 1994, he was inducted into the International Association of Jazz Educators Hall of Fame. He also enjoyed working during the summers at Jamey Aebersold's jazz camps all over the world. ${ }^{12}$

DAN HAERLE was born in Quincy, Illinois in 1937. In 1953, he moved to New York where he attended Flushing High School (junior year) and graduated from Hicksville High School in 1955. In 1957, he moved to Cedar Rapids, Iowa where he attended Coe College and graduated in 1961. He was a faculty member in the Jazz Studies Division of the College of Music at the University of North Texas for 25 years from 1977-2002. He taught Jazz Piano, Jazz Fundamentals, Advanced Jazz Improvisation, Jazz MIDI, Graduate Jazz Improvisation, Rhythm Section Master Class, and he supervised the jazz chamber music program. He directed the Jazz Strings and a keyboard ensemble called The Zebras. He taught the courses in basic MIDI theory, sequencing and jazz notation. In 2007, he was named Professor Emeritus. In 2008, Dan joined the faculty of the Dallas School of Music where he presently teaches. He also taught at Kansas State University, Monterey Peninsula College, (CA), the University of Miami, and Arizona State University. In 2012, the Jazz Education Network (JEN) awarded Dan (along with Jamey Aebersold, David Baker, and Jerry Coker) the distinction of "LeJENd of Jazz Education" at its 3rd annual conference in Louisville, Kentucky. He has recorded many Jamey Aebersold play-a-longs, has several jazz text books

12 "Jerry Coker Biography," Allmusic.com accessed October 2, 2013 http://www.allmusic.com/artist/jerry-coker-mn0000273592/biography and http://utdailybeacon.com/news/1998/jan/16. 
published, is an active jazz clinician nationally and internationally, and has had a great deal of performing experience. ${ }^{13}$

RUFUS REID is one of today's premiere bassists on the international jazz scene. $\mathrm{He}$ is equally known as an exceptional educator. Dr. Martin Krivin and Reid created the Jazz Studies \& Performance Program at William Paterson University. Reid retired after 20 years, but continues to teach, conducting Master Classes, workshops, and residencies around the world. Born in 1944 in Atlanta, GA., Rufus Reid was raised in Sacramento, California, where he played the trumpet through junior high and high school. Upon graduation from Sacramento High School, he entered the United States Air Force as a trumpet player, but he began to be seriously interested in the bass. After fulfilling his duties in the military, Rufus decided to pursue a career as a professional bassist. He studied with James Harnett of the Seattle Symphony, and Warren Benfield and Joseph Guastefeste both of the Chicago Symphony. He graduated from Northwestern University in 1971 with a Bachelor of Music Degree as a Performance Major on the Double Bass. Rufus' book, The Evolving Bassist, published since 1974, continues to be recognized as the industry standard as the definitive bass method. He has toured and recorded with Eddie Harris, Nancy Wilson, Harold Land \& Bobby Hutcherson, Lee Konitz, The Thad Jones \& Mel Lewis Jazz Orchestra, Dexter Gordon, J.J. Johnson, Art Farmer, Stan Getz, Kenny Burrell, Kenny Barron, and countless others. ${ }^{14}$

JERRY TOLSON is professor of jazz studies and music education at the University of Louisville, where he is chair of the music education division, directs instrumental and vocal jazz ensembles and teaches jazz pedagogy, jazz style, jazz history, and African American Music classes. He is a clinician for Alfred Music, a consultant for Pearson Educational Publishing, and serves as an adjudicator, guest conductor, and jazz camp instructor internationally. Tolson has presented at state, regional, and national Music Education conferences, the International Association for Jazz Education Conference, Jazz Education Network, the International Academy of Law and Mental Health, and the Midwest Clinic. He is the educational director for the University of Louisville Jazz Festival and co-founder of U of L's African American Music

13 "Bio" Dan Haerle's homepage, accessed October 2, 2013, http://www.danhaerle.com/bio.html.

14 "Biography" Rufus Reid's homepage, accessed October 2, 2013, http://rufusreid.com/about/biography/. 
Heritage Institute, a celebration of the contributions of African Americans to America's musical history, as well a series of jazz teacher training institutes. Tolson's articles have appeared in Music Educator's Journal, Jazz Educator's Journal, and The Instrumentalist, and he is a contributor to the following publications: Teaching Music Through Performance in Jazz, (ed. Carter and Miles), Jazz Pedagogy: The Jazz Educator's Handbook and Resource Guide (Dunscomb and Hill), and The Jazzer's Cookbook: Creative Recipes for Players and Teachers. As a composer/arranger Tolson writes for both large and small instrumental ensembles as well as vocal jazz ensembles. His vocal jazz arrangements are published by UNC Jazz Press.

Performing on keyboards, woodwinds, and vocals, Tolson leads three groups and has worked with artists such as Delfeayo Marsalis, Antonio Hart, Don Braden, Rufus Reid, Kevin Mahogany, James Moody, Benny Golson, and Grace Kelley. Tolson's CDs include Nu View, Back at the Track, and Fresh Squeezed, and his groups have appeared at the Montreux Jazz Festival in Switzerland, the Umbria Jazz Festival in Italy, and in Barbados, Brazil, and Trinidad. 